\title{
Effect of substituting milfoil, St. Johnswort and lovage for antibiotics on chicken performance and meat quality
}

\section{Zofia Fritz, Alina Schleicher and Stefania Kinal}

\author{
Department of Animal Nutrition and Feed Sciences, Wroclaw Agricultural University \\ ul. Norwida 25/27, 50-375 Wroclaw, Poland
}

(Received 31 May, 1993; accepted 17 September, 1993)

\begin{abstract}
One thousand one-day-old broiler chicks were divided into 5 experimental groups: the control groups received an antibiotic in their feed, the remaining groups $-3 \%$ dried milfoil (Achillea millefolium L.) and St. Johnswort (Hypericum perforatum L.) herbage and lovage roots (Levisticum officinale Koch) mixed in various proportions. Body weight gain and feed utilization over a 9-week period of the experiment were similar in the experimental and control groups. A beneficial effect of milfoil on body weight gain of chicks was found. Milfoil in combination with St. Johnswort affected positively the sensory characteristics of meat.
\end{abstract}

KEY WORDS: broilers, antibiotic, herbs, sensory characteristics of meat

\section{INTRODUCTION}

Interest in medicinal herbs as natural sources of substances affecting numerous physiological processes in the living organism has been growing over recent years. This has stimulated attempts to use herbs as additives to poultry feeds (Fritz et al., 1990; Pradhan and Misra, 1988; Wężyk et al., 1992). By using our own herbal mixtures comprising several types of herbs (Fritz et al., 1990, 1992) we have shown that they can replace antibiotics in feeds for broiler chicks and have a positive influence on body weight gain and feed utilization. A tendency for improved sensory characteristics (tenderness, colour and taste) of meat has also been demonstrated (Fritz et al., 1990, 1993). Taking into account these data and the taste preferences of chicks, numerous herbs were examined in order to find one herb or a mixture of herbs whose effects would be both reproducible and promote optimal performance. The feed additives used in the 
current experiment were dried milfoil (Achillea millefolium L.) and St. Johnswort (Hypericum perforatum L.) herbage and dried lovage (Levisticum officinale Koch.) roots, mixed in various proportions.

\section{Material and Methods}

The experiment was carried out on 1000 one-day-old Astra B broilers of both sexes divided into 5 groups of 200 birds and each group was further divided into four sub-groups. The birds were raised until 9 weeks of age, i.e. until they reached „heavy" broiler weight.

The chicks were kept under standard conditions on sawdust with free access to feed and water. For the first two weeks the chicks were given a starter feed, from week 3 to $7-$ a grower feed and from week 7 to $9-$ a finisher feed. The isoprotein diets were composed of maize, wheat, soya bean oil meal, meat-and-bone meal, mineral and vitamin supplements and contained during the successive phases of the experiment: 22,20 and $19 \%$ crude protein and about $12 \mathrm{MJ}$ metabolizable energy $/ \mathrm{kg}$.

Control group I received the antibiotic (avoparcine), both in starter and grower feeds ( $7 \mathrm{mg} / \mathrm{kg}$ feed), while control group II only in starter feed, after which $3 \%$ milfoil was added to the grower and finisher feeds. The experimental groups did not receive any antibiotic; instead, during the entire experiment they received a $3 \%$ supplement of the following herbs: group III - milfoil, IV - milfoil and St. Johnswort (40:60), V - milfoil, St. Johnswort and lovage root (65:30:5). The metabolizable energy content was $0.2 \mathrm{MJ} / \mathrm{kg}$ lower in the experimental feeds, and the crude fibre content $0.6 \%$ higher than in the control feed. The chicks were weighed after 3,7 and 9 weeks of the experiment and feed intake per $\mathrm{kg}$ of body weight gain was estimated.

At the end of the experiment, blood was sampled from 8 birds in each group and its morphological composition, $\mathrm{Hb}$ level, $\mathrm{Ht}$, uric acid, and ALAT and AspAT activities, and $\mathrm{Ca}$ and $\mathrm{P}$ content were determined using conventional methods and kits from POCh (Gliwice, Poland).

At the end of the experiment 40 cockerels and 40 pullets having the average weight for the given group were slaughtered and dressing percentage, proportion of breast muscle, giblets, liver and abdominal fat in the carcass were determined. The dry matter content in the breast muscles and their water binding capacity were determined using a modified Grau-Hamm method (Szmańko, 1985), colour was assessed spectrophotometrically (Duda, 1978; Stępień, 1993). A sensory evaluation of the meat was carried out according to the method described by Baryłko-Pikielna (1981) and Mead (1985).

The results were subjected to statistical evaluation using stanard methods. 


\section{Results and Discussion}

The herbs used in this study contained 7 to $11 \%$ crude protein, $3-7 \%$ crude fat and about $29 \%$ crude fibre (Table 1 ).

TABLE 1

Chemical composition of herbages, $\%$

\begin{tabular}{lrcr}
\hline \multirow{2}{*}{ Nutrients } & \multicolumn{3}{c}{ Herbages } \\
\cline { 2 - 4 } & milfoil & common St. Johnswort & lovage \\
\hline Dry matter & 86.75 & 87.60 & 83.65 \\
Crude protein & 11.22 & 7.59 & 7.22 \\
Crude fibre & 29.82 & 29.60 & 7.65 \\
Crude fat & 7.45 & 3.40 & 3.80 \\
N-frec extractives & 31.31 & 43.16 & 60.98 \\
Crude ash & 6.95 & 3.85 & 4.00 \\
\hline
\end{tabular}

TABLE 2

Performance of broilers

\begin{tabular}{|c|c|c|c|c|c|c|}
\hline \multirow[b]{2}{*}{ Indices } & & \multicolumn{5}{|c|}{ Groups } \\
\hline & & $\frac{\text { I }}{\text { antibiotic }}$ & $\begin{array}{c}\text { II } \\
\text { antibiotic } \\
\text { milfoil }\end{array}$ & $\begin{array}{l}\text { III } \\
\text { milfoil }\end{array}$ & $\begin{array}{l}\text { IV } \\
\text { milfoil } \\
\text { common } \\
\text { St. Johns- } \\
\text { wort }\end{array}$ & $\begin{array}{c}\mathrm{V} \\
\text { milfoil } \\
\text { common } \\
\text { St. Johns- } \\
\text { wort lovage }\end{array}$ \\
\hline \multicolumn{7}{|c|}{ Body weight of chicks, g } \\
\hline 3 weeks & $\delta+q$ & 486 & 499 & 498 & 506 & 471 \\
\hline \multirow[t]{3}{*}{7 weeks } & 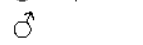 & 1917 & 1890 & 1930 & 1904 & 1883 \\
\hline & 운 & 1675 & 1630 & 1662 & 1582 & 1642 \\
\hline & $\frac{\ddagger}{\mathbf{x}}$ & 1796 & 1760 & 1796 & 1743 & 1762 \\
\hline \multirow[t]{3}{*}{9 weeks } & 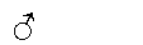 & 2666 & 2707 & 2757 & 2634 & 2598 \\
\hline & $q$ & 2267 & 2295 & 2284 & 2192 & 2254 \\
\hline & $\frac{\bar{x}}{\mathrm{x}}$ & $2466^{\mathrm{ABab}}$ & $2501^{\mathrm{a}}$ & $2520^{\mathrm{Aa}}$ & $2413^{\mathrm{Bb}}$ & $2426^{b}$ \\
\hline \multicolumn{7}{|c|}{ Feed $\mathrm{kg} / \mathrm{kg}$ of body weight gain } \\
\hline 0-3 wee & & 1.91 & 1.90 & 1.93 & 1.93 & 2.06 \\
\hline $0-7$ wee & & 2.53 & 2.55 & 2.55 & 2.59 & 2.65 \\
\hline $0-9$ wee & & 2.85 & 2.92 & 2.85 & 2.85 & 2.94 \\
\hline Mortality & weeks, $\%$ & 3.0 & 4.0 & 3.0 & 3.5 & 4.0 \\
\hline
\end{tabular}

The means signed with different letters are significantly different: $A, B-P<0.01, a, b-P<0.05$ 
The body weight of the chickens in all of the groups after 3 and 7 weeks was similar (Table 2). Significant differences among the groups were not apparent before the birds reached 9 weeks of age. The birds receiving only milfoil (group III) were the heaviest. The broilers from control groups I and II weighed 1 to $2 \%$ less $(\mathrm{P}<0.05$ ), and those from group IV (milfoil and St. Johnswort) and V (milfoil, St. Johnswort and lovage) weighed from $3 \%$ to $4 \%$ less than those from group III $(\mathrm{P} \leqslant 0.01$ and 0.05$)$.

Feed utilization in the groups of chicks given the antibiotic or herb-containing feeds were, in the particular phases of the experiment, very similar and amounted to $1.9 \mathrm{~kg} / \mathrm{kg}$ body weight gain in the first 3 weeks of life and about $2.9 \mathrm{~kg} / \mathrm{kg}$ body weight gain over the entire period of the experiment.

Analysis of blood samples revealed significant differences among the groups only in the level of uric acid and transaminase activity (ALAT and AspAT) (Table 3). Although transaminase activity was the highest in the groups of birds receiving the herb-containing feeds, it still remained within normal physiological limits (Sturkie, 1970). The highest level of uric acid was found in the serum of birds receiving a mixture of milfoil, lovage and St. Johnswort $(\mathrm{P} \leqslant 0.01)$, which could be related to the somewhat worse utilization of feed, thus of protein, in this group of birds. The $\mathrm{Ca}$ and $\mathrm{P}$ levels were similar in all the studied groups.

TABLE 3

Blood analysis

\begin{tabular}{|c|c|c|c|c|c|c|}
\hline \multirow[t]{2}{*}{ Indices } & \multicolumn{5}{|c|}{ Groups } & \multirow[b]{2}{*}{ SEM } \\
\hline & I & II & III & IV & $\mathrm{V}$ & \\
\hline Erythrocytes $10^{12} / 1$ & 3.07 & 2.92 & 3.12 & 3.45 & 3.33 & 0.4479 \\
\hline Leucocytes $10^{9} / 1$ & 29.2 & 26.8 & 29.2 & 32.1 & 28.2 & 7.0695 \\
\hline $\mathrm{Hb} \quad \mathrm{mmol} / 1$ & 5.43 & 5.33 & 5.64 & 5.31 & 5.95 & 0.5774 \\
\hline $1 / 1$ & 0.29 & 0.29 & 0.28 & 0.29 & 0.29 & 0.1895 \\
\hline AlAT & $7.53^{\mathrm{Aa}}$ & $6.37^{\mathrm{ABab}}$ & $5.56^{\mathrm{B}}$ & $5.83^{\mathrm{B}}$ & $5.96^{\mathrm{b}}$ & 1.2462 \\
\hline AspAT unit & $6.11^{\mathrm{Aa}}$ & $5.66^{\mathrm{ABab}}$ & $5.60^{\mathrm{b}}$ & $5.68^{\mathrm{ABab}}$ & $5.26^{\mathrm{B}}$ & 0.5495 \\
\hline Uric acid $\mathrm{mg} / 100 \mathrm{ml}$ & $5.82^{\mathrm{A}}$ & $5.55^{\mathrm{A}}$ & $4.96^{\mathrm{A}}$ & $5.26^{\mathrm{B}}$ & $7.05^{\mathrm{B}}$ & 1.2331 \\
\hline $\mathrm{Ca} \quad \mathrm{mmol} / 1$ & 2.79 & 2.69 & 2.65 & 2.65 & 2.46 & 0.2337 \\
\hline $\mathrm{mmol} / 1$ & 2.23 & 2.08 & 1.91 & 1.97 & 1.96 & 0.2923 \\
\hline
\end{tabular}

The means signed with different letters are significantly different: $\mathrm{AB}=\mathrm{P}<0.01 ; \mathrm{a}, \mathrm{b}=\mathrm{P}<0.05$

Dissection (Table 4) revealed a notably higher content of abdominal fat in the carcasses of birds from the group receiving a mixture of milfoil, St. Johnswort and lovage. There were no statistically significant differences among the groups in relation to the remaining dissection parameters. The dry matter content and 
water binding capacity of the breast muscle were similar in all of the studied groups.

TABLE 4

Slaughter results

\begin{tabular}{lcccccr}
\hline \multicolumn{1}{c}{ Indices } & \multicolumn{7}{c}{ Groups } & \\
\cline { 2 - 6 } & I & II & III & IV & V & SEM \\
\hline $\begin{array}{l}\text { Dressing percentage } \\
\text { \% }\end{array}$ & 72.44 & 71.70 & 71.94 & 70.60 & 71.35 & 0.1584 \\
\hline $\begin{array}{l}\text { Percent of empty body } \\
\text { Breast muscle }\end{array}$ & 19.84 & 19.43 & 19.32 & 18.97 & 20.21 & 1.5893 \\
Giblets & 5.80 & 5.59 & 5.91 & 6.26 & 6.00 & 0.5948 \\
Liver & 3.08 & 2.67 & 2.82 & 3.02 & 2.94 & 0.4244 \\
Abdominal fat & $2.29^{\mathrm{a}}$ & $2.37^{\text {ABab }}$ & $2.15^{\mathrm{A}}$ & $2.57^{\mathrm{ABab}}$ & $2.74^{\mathrm{Bb}}$ & 0.7193 \\
\hline Meat dry matter & 26.08 & 26.02 & 25.97 & 25.90 & 25.97 & 0.9745 \\
Water binding & 56.30 & 56.79 & 54.81 & 57.19 & 56.10 & 4.4284 \\
capacity & & & & & & \\
\hline
\end{tabular}

the means signed with different letters are significantly different: $A, B=P<0.01 ; a, b=P<0.05$

Significant differences among groups were found, however, in the juiciness, tenderness and palatability of meat (Table 5). The remaining parameters such as flavour and colour of the meat did not differ significantly among the groups. The colour of the meat from the group receiving milfoil and St. Johnswort (IV) was graded slightly higher. It can be assumed that the naphthobianthrone pigment in the St. Johnswort may have affected meat colour. The meat from chicks receiving the feed containing only milfoil (III) received the lowest score for tenderness; the meat from the groups fed the diet containing milfoil and St. Johnswort (IV) was judged the juiciest. The latter also received the highest score for palatability, 4.3 points, while the lowest score, 3.5 points, for this trait was given to the meat from group III birds (only milfoil) $(\mathrm{P} \leqslant 0.01)$. Of the 5 evaluated sensory parameters (flavour, colour, palatability, juiciness), 4 were the highest in the meat from chickens receiving feeds containing milfoil and St. Johnswort (IV). This had a decisive effect on the final score, which was $5.3 \%$ higher than in the control group. In a previous experiment (Fritz et al., 1993), feeding chickens herbal mixtures containing significant proportions of milfoil and St. Johnswort improved the juiciness, palatability and colour of meat as compared with meat from chickens that were not fed herbs.

A spectrometric method was used in addition to sensory evaluation in order to rate meat colour, an important criterion from the consumer point of view. By this method, meat from the control group (I) receiving the antibiotic and meat from group IV (milfoil with St. Johnswort) received the best grades. This 
evaluation applied both to photometric clarity as well as colour saturation and tone (Table 5). The somewhat higher saturation of the colour of the meat from these groups may indicate the greater intensity of red, which is considered a favourable trait (Skrabka-Błotnicka and Rumilak, 1991). All of the parameters related to meat colour were significantly inferior in the group of birds fed a mixture of milfoil, lovage and St. Johnswort (V). The studies by Jamroz et al. (1992) point to the favourable effect of antibiotics (avoparcine, lincomycin) on the colour of chicken meat. The results obtained by Bodkowski et al. (1993) in an experiment conducted on lambs indicate that the addition of herbs to feeds results in a rise in the amount of pigments in the muscle tissue of animals, which is in agreement with the results of the study reported here.

TABLE 5

Sensoric evaluation of meat (points) and spectrophotometric estimation of meat colour

\begin{tabular}{|c|c|c|c|c|c|c|}
\hline \multirow[t]{2}{*}{ Traits of meat } & \multicolumn{5}{|c|}{ Groups } & \multirow[b]{2}{*}{ SEM } \\
\hline & I & II & III & IV & $\mathrm{V}$ & \\
\hline Smell & 4.34 & 4.36 & 4.14 & 4.53 & 4.51 & 0.5158 \\
\hline Colour & 4.34 & 4.41 & 4.30 & 4.68 & 4.51 & 0.5020 \\
\hline Palatability & $4.02^{\mathrm{ABa}}$ & $3.77^{\mathrm{ABabc}}$ & $3.48^{\mathrm{Abc}}$ & $4.31^{\text {Babd }}$ & $3.83^{\mathrm{ABabc}}$ & 0.5514 \\
\hline Juiciness & $3.82^{\mathrm{AB}}$ & $3.63^{A}$ & $3.40^{\mathrm{A}}$ & $4.22^{B}$ & $3.60^{\mathrm{A}}$ & 0.5802 \\
\hline Tendernes & $4.39^{\mathrm{Aa}}$ & $4.39^{\mathrm{Aa}}$ & $3.86^{\mathrm{Bab}}$ & $4.28^{\mathrm{ABac}}$ & $4.00^{\mathrm{ABbc}}$ & 0.4619 \\
\hline $\begin{array}{r}\text { Points total } \\
\%\end{array}$ & $\begin{array}{l}20.91 \\
100\end{array}$ & $\begin{array}{l}20.56 \\
98.3\end{array}$ & $\begin{array}{l}19.18 \\
91.7\end{array}$ & $\begin{array}{l}22.02 \\
105.3\end{array}$ & $\begin{array}{l}20.45 \\
97.8\end{array}$ & \\
\hline $\begin{array}{l}\gamma \text { photometric light } \\
\mathrm{Pe}-\text { saturation } \\
\lambda \mathrm{d} \text { tone colour }\end{array}$ & $\begin{array}{c}30.8^{\mathrm{a}} \\
0.419^{\mathrm{a}} \\
601.6^{\mathrm{a}}\end{array}$ & $\begin{array}{c}33.1^{\mathrm{ab}} \\
0.415^{\mathrm{ab}} \\
600.9^{\mathrm{ab}}\end{array}$ & $\begin{array}{c}32.6^{\mathrm{ab}} \\
0.412^{\mathrm{ab}} \\
600.5^{\mathrm{ab}}\end{array}$ & $\begin{array}{c}31.7^{\mathrm{ab}} \\
0.419^{\mathrm{a}} \\
601.8^{\mathrm{a}}\end{array}$ & $\begin{array}{l}33.4^{\mathrm{b}} \\
0.411^{\mathrm{b}} \\
599.8^{\mathrm{b}}\end{array}$ & $\begin{array}{l}2.3382 \\
0.0074 \\
1.5775\end{array}$ \\
\hline
\end{tabular}

the means signed with different letters are significantly different: $A, B=P<0.01 ; a, b=P<0.05$

In our experiment, the cost of feeds containing antibiotics was similar to the cost of feeds containing herbs.

The results presented above indicate that the addition of appropriately selected herbs can replace antibiotics in feeds for broilers and improve the sensory characteristics of meat.

\section{REFERENCES}

Baryłko-Pikielna N., 1981. Zarys analizy sensorycznej żywności. WNT, Warszawa

Bodkowski R., Patkowska-Sokola B., Szymańko T., 1993. Wpływ dodatku naturalnych biostymulatorów na użytkowość mięsna jagniąt oraz opłacalność tuczu. Rocz. Nauk. Zoot. (in press) Duda Z., 1978. Przewodnik do ćwiczeń z technologii mięsa, drobiu i jaj oraz mleczarstwa. Ed. AR Wrocław 
Fritz Z., Majdański F., Kinal S., Schleicher A., 1990. Ziola jako komponent mieszanek paszowych dla kurcząt brojlerów. Zesz. Nauk. Drob. 7, $31-40$

Fritz Z., Schleicher A., Kinal S., Jarosz L., Majdański F., 1992. Zastąpienie antybiotyku ziołami w mieszankach dla kurcząt rzeźnych. Rocz. Nauk. Zoot., Monogr. Rozpr. 31, 315--325

Fritz Z., Kinal S., Schleicher A., 1993. Wpływ podawania kurczętom rzeźnym mieszanek z udziałem ziół i preparatu torfowego na wskażniki hemotologiczne, dysekcyjne, histologiczne i jakość mięsa. Zesz. Nauk. AR Wrocław (in press)

Jamroz D., Schleicher A., Wiliczkiewicz A., Skorupińska J., Hajduczenia E., 1992. Wpływ antybiotyków paszowych na składniki morfotyczne i mineralne krwi oraz jakość mięsa kurcząt rzeźnych. Rocz. Nauk. Zoot. 19, 149165

Mead G.C., 1985. Working Group Report. Recommendation of a standarized method of sensory analysis for broilers. A Report of Working Group 5 - Poultry Meat Quality of the EF of WPSA. 64-67

Pradhan N.R., Misra S.K., 1988. Effect of feeding „livol" on the egg production of layers. Indian Vet.J., $65,714-718$

Skrabka-Blotnicka T., Rumilak K., 1991. Próby zastosowania naturalnych barwników w przetwórstwie mięsnym. Gosp. Mięsna, 43, (11) 6-7

Stępień A., 1993. W pływ dodatku antybiotyk u lub ziół do mieszanek treściwych dla kurcząt rzeźnych na cechy jakościowe mięsa. MSc degree. Department of Animal Nutrition nad Feed Sciences, Wroclaw Agricultural Uniwersity

Sturkic P.D., 1970. Fizjologia ptaków. PWRiL, Warszawa

Szymańko T., 1985. Urządzenie do pomiaru zdolności utrzymania wody. Wz. użytkowy 40767. Ed. AR Wrocław

Wężyk S., Koloszko Z., Mlodkowski M., 1992. Wplyw dodatku do mieszanek dla kur niosek suszu z poekstrakcyjnych odpadów pokrzywy i tataraku na zabarwienie żółtek jaj. Rocz. Nauk. rol., Ser. B, $108(1-2) 91-102$

\section{STRESZCZENIE}

Wplyw zastapienia antybiotyku krwawnikiem, dziurawcem i lubczykiem na wyniki tuczu kurcząt oraz jakość mięsa

Tysiąc jednodniowych kurcząt brojlerów podzielono na 5 grup doświadczalnych. Grupy kontrolne (I i Il) otrzymywały w paszy antybiotyk, a pozostałe (III-V) 3\% dodatek ziela krwawnika, dziurawca i korzenia lubczyka zmieszane w różnych proporcjach. Odchów kurcząt prowadzono przez 9 tygodni. Przyrosty masy ciała i wykorzystanie paszy bylo przy stosowaniu ziól podobne jak w grupie kontrolnej. Stwierdzono korzystny wpływ krwawnika na przyrost kurcząt, a w połączeniu $z$ dziurawcem na cechy sensoryczne mięsa. 